Effects of sample mass and macrofossil type on radiocarbon dating of arctic and boreal lake sediments

W. W. Oswald, P. M. Anderson, T. A. Brown, L. B. Brubaker, F. S. Hu, A. V. Lozhkin, W. Tinner, P. Kaltenrieder

May 31, 2006

The Holocene 
This document was prepared as an account of work sponsored by an agency of the United States Government. Neither the United States Government nor the University of California nor any of their employees, makes any warranty, express or implied, or assumes any legal liability or responsibility for the accuracy, completeness, or usefulness of any information, apparatus, product, or process disclosed, or represents that its use would not infringe privately owned rights. Reference herein to any specific commercial product, process, or service by trade name, trademark, manufacturer, or otherwise, does not necessarily constitute or imply its endorsement, recommendation, or favoring by the United States Government or the University of California. The views and opinions of authors expressed herein do not necessarily state or reflect those of the United States Government or the University of California, and shall not be used for advertising or product endorsement purposes. 
Effects of sample mass and macrofossil type on radiocarbon dating of arctic and boreal lake sediments

W. Wyatt Oswald ${ }^{1,2, *}$

Patricia M. Anderson ${ }^{2}$

Thomas A. Brown ${ }^{3}$

Linda B. Brubaker ${ }^{1}$

Feng Sheng $\mathrm{Hu}^{4}$

Anatoly V. Lozhkin ${ }^{5}$

Willy Tinner ${ }^{6}$

Petra Kaltenrieder ${ }^{6}$

${ }^{1}$ College of Forest Resources, University of Washington, Seattle, WA, USA

${ }^{2}$ Quaternary Research Center, University of Washington, Seattle, WA, USA

${ }^{3}$ Center for Accelerator Mass Spectrometry, Lawrence Livermore National Laboratory, Livermore, CA, USA

${ }^{4}$ Departments of Plant Biology and Geology, University of Illinois, Urbana, IL, USA

${ }^{5}$ North East Interdisciplinary Research Institute, Far East Branch, Russian Academy of

Science, Magadan, Russia

${ }^{6}$ Institute of Plant Sciences, University of Bern, Bern, Switzerland

*Current address for correspondence

W. Wyatt Oswald

Harvard Forest

Harvard University

P. O. Box 68

Petersham, MA 01366, USA

Phone: (978) 724-3302

Fax: (978) 724-3595

Email: woswald@fas.harvard.edu

Running title: Radiocarbon dating of northern lake sediments

August 18, 2004 


\begin{abstract}
Dating lake sediments by accelerator mass spectrometry (AMS) ${ }^{14} \mathrm{C}$ analysis of plant macrofossils overcomes one of the main problems associated with dating bulk sediment samples, the presence of old organic matter. Even so, many AMS dates from arctic and boreal sites appear to misrepresent the age of the sediment. To understand the nature of these apparent dating anomalies better, we conducted a series of ${ }^{14} \mathrm{C}$ dating experiments using samples from Alaskan and Siberian lake-sediment cores. First, to test whether our analytical procedures introduced a sample-mass bias, we obtained ${ }^{14} \mathrm{C}$ dates for differentsized pieces of single woody macrofossils. In these sample-mass experiments, statistically equivalent ages were found for samples as small as $0.05 \mathrm{mg} \mathrm{C}$. Second, to assess whether macrofossil type influenced dating results, we conducted sample-type experiments in which ${ }^{14} \mathrm{C}$ dates were obtained for different macrofossil types sieved from the same depth in the sediment. We dated materials from multiple levels in sediment cores from Upper Capsule Lake (North Slope, northern Alaska) and Grizzly Lake
\end{abstract}

(Copper River Basin, southern Alaska), and from single depths in other records from northern Alaska. In several of the experiments there were significant discrepancies between dates for different plant tissues, and in most cases wood and charcoal were older than other macrofossil types, usually by several hundred years. This pattern suggests that

${ }^{14} \mathrm{C}$ dates for woody macrofossils may misrepresent the age of the sediment by centuries, perhaps due to their longer terrestrial residence time and the potential in-built age of long-lived plants. This study identifies why some ${ }^{14} \mathrm{C}$ dates appear to be inconsistent with the overall age-depth trend of a lake-sediment record, and it may guide the selection of ${ }^{14} \mathrm{C}$ samples in future studies.

Key words: Alaska, AMS, chronology, Holocene, paleoecology, Siberia

\title{
INTRODUCTION
}

High-quality chronology is vital in Quaternary sciences, particularly in efforts to understand rates of ecosystem response to environmental change and feedbacks between the geosphere and biosphere (e.g., Sarnthein et al., 2000). Lake-sediment records are examined widely for the variety of information they contain about the past, including 
rapid environmental and ecosystem variability (e.g., Allen et al., 1999; Newnham and Lowe, 2000; Clark et al., 2002). In general the chronology of these records is based on ${ }^{14} \mathrm{C}$ dating. Prior to the development of accelerator mass spectrometry (AMS), lake records were usually dated via ${ }^{14} \mathrm{C}$ analysis of bulk sediment, which in some circumstances may be complicated by the presence of old organic matter in the sediment matrix (e.g., Olsson, 1974). This problem may be acute at the northernmost latitudes, where organic matter decomposes slowly and may reside in permafrost for long periods of time before being eroded into lake basins (e.g., Nelson et al., 1988; Zimov et al., 1997). The development of AMS ${ }^{14} \mathrm{C}$ dating has made it possible to obtain ages for individual plant macrofossils, potentially avoiding problems associated with dating mixtures of contemporaneous and older organic matter in bulk sediment. When both techniques are applied to the same stratigraphic record, ages for AMS-dated plant macrofossils are often found to be hundreds or even thousands of years younger than ages for bulk sediment from the same core depth (e.g., Cwynar and Watts, 1989; Törnqvist et al., 1992; Bigelow and Edwards, 2001). However, AMS dating is not free of problems, especially in arctic and boreal regions. Many AMS-dated sediment cores from Alaska and northeastern Siberia suffer from age reversals: dates that are anomalously old or young compared with the age-depth relationship for the majority of dates from a core (e.g., Oswald et al., 1999; Brubaker et al., 2001; Lozhkin et al., 2001; Mann et al., 2002).

AMS analyses of standardized laboratory samples have demonstrated that reasonable analytical precision can be obtained for samples $<2 \mathrm{mg}$ (e.g., Kirner et al., 1996; Brown and Southon, 1997; Von Reden et al., 1998; Hua et al., 2001). The possibility of obtaining dates from small macrofossils is a major advantage of AMS when dating records from northern lakes, for which in many cases only small plant fragments are preserved in the sediment. However, when age reversals occur at such sites they often involve relatively small samples, and in most cases the problematic dates are younger than would be expected based on the age-depth trend (e.g., Oswald et al., 1999; Andreev et al., 2001). Given these observations, the first set of experiments in this study was used to test whether our analytical procedures result in an age bias at some sample-mass 
threshold. In these experiments, plant macrofossils found in Alaskan and Siberian sediment cores were split into different-sized pieces and then analyzed for ${ }^{14} \mathrm{C}$ age.

Issues related to sample type arise because lake sediments from arctic and boreal regions often have few macrofossils. In most cases a single type of macrofossil is not present throughout a core, and therefore the chronology for the record is based on ages from a variety of different macrofossil types (e.g., seeds, wood, moss, leaves from different taxa). Aquatic plant macrofossils from hard-water lakes in carbonate terrain are usually not dated due to the possibility of old-carbon reservoir effects (e.g., Deevey et al., 1954; MacDonald et al., 1987; Hu et al., 1996), whereas aquatic plants from soft-water lakes have been shown to be equilibrated with atmospheric $\mathrm{CO}_{2}$ (Abbott and Stafford, 1996; Miller et al., 1999), and thus their macrofossils may be an appropriate target material for

${ }^{14} \mathrm{C}$ dating. However, little is known of systematic biases in the ${ }^{14} \mathrm{C}$ ages of terrestrial plant macrofossils that are commonly analyzed. Such biases might arise from differences in taphonomy, "in-built age" (e.g., McFadgen, 1982), or susceptibility of the sample to contamination by young or old carbon. To test the importance of sample type, dates were obtained for several types of plant macrofossil from the same depth in sediment cores. These macrofossil-type experiments were conducted at multiple levels in cores from two sites in Alaska: Grizzly and Upper Capsule lakes. These sites were selected for analysis because (1) the sediment cores contained a variety of macrofossils, and (2) they are representative of boreal forest and arctic tundra ecosystems. The findings from these sites were supplemented by opportunistic, single-level experiments from several other sediment cores from northern Alaska.

\section{STUDY SITES}

Upper Capsule Lake (informal name; $68^{\circ} 38^{\prime} \mathrm{N}, 149^{\circ} 25^{\prime} \mathrm{W}$ ) is located in the Arctic Foothills of northern Alaska (Fig. 1). This area has a mean July temperature of $11^{\circ} \mathrm{C}$, a mean January temperature of $-22^{\circ} \mathrm{C}$, and $325 \mathrm{~mm}$ mean annual precipitation (Zhang et al., 1996). The Upper Capsule watershed is currently dominated by moist dwarf-shrub tussock-graminoid tundra (Walker et al., 1994; Muller et al., 1999), with moist, acidic, organic soils (Bockheim et al., 1998). The site is underlain by continuous permafrost, 
with a shallow thaw layer (e.g., Walker et al., 2001). The pollen record from Upper Capsule Lake suggests that relatively xeric, discontinuous vegetation occurred during the early Holocene, and that a transition to the modern ecosystem took place as effective moisture increased between $\sim 10,000$ and 7500 cal years BP (Oswald et al., 2003). The timing of an increase in Alnus pollen percentages at Upper Capsule and other nearby sites (e.g., Oswald et al., 1999) provides an age-depth reference point to help evaluate the chronology of the sediment record (Fig. 2).

Grizzly Lake $\left(62^{\circ} 43^{\prime} \mathrm{N}, 144^{\circ} 12^{\prime} \mathrm{W}\right)$ is located in the Copper River Basin of southern Alaska (Fig. 1). This area has a mean July temperature of $13.4^{\circ} \mathrm{C}$, a mean January temperature of $-20.2^{\circ} \mathrm{C}$, and $390 \mathrm{~mm}$ mean annual precipitation (Western Regional Climate Center, 2002). Permafrost is discontinuous, and moraines near the lake have well-drained soils. Forests near Grizzly Lake are dominated by Picea glauca, Betula papyrifera, and Populus tremuloides. Picea mariana forms nearly pure stands in areas of wet soils, and Alnus crispa occurs on south-facing slopes. The pollen record from Grizzly Lake (W. Tinner, unpublished data) suggests that Betula papyrifera, Betula nana/glandulosa, and Populus dominated the vegetation before 9300 cal years BP, and that Picea glauca forest replaced the open Betula-Populus stands between 9300 and 8500 cal years BP. Alnus crispa expanded $\sim 8500$ cal years BP, and Picea mariana became abundant after $\sim 7000$ cal years BP, apparently reducing soil erosion in the watershed and decreasing the sedimentation rate. Additional experiments were conducted using samples from several other sites in Alaska and Siberia (Fig. 1). All of these sites occur in areas of arctic or boreal vegetation (Table 1).

\section{METHODS}

$\underline{\text { Sampling, pre-treatment, and }{ }^{14} \mathrm{C} \text { age determination }}$

Sediment cores were collected from the study lakes using a modified square-rod pistonsampler $4.5 \mathrm{~cm}$ in diameter (Wright et al., 1984). At selected core depths, $1-2 \mathrm{~cm}$ sections of the core were washed through a 500- $\mu \mathrm{m}$ mesh screen with distilled water. The $>500-\mu \mathrm{m}$ fraction was examined using a dissecting microscope, and plant macrofossils were removed using clean tweezers. We selected levels with large pieces of 
wood and abundant macrofossils for the sample-mass and macrofossil-type experiments, respectively. For the sample-mass experiments, woody macrofossils were split into two to six different-sized pieces using a sharp, clean blade. For the sample-type experiments, two to seven different plant macrofossils were chosen from a single sediment sample 1-2 $\mathrm{cm}$ thick. To remove exterior contaminants, samples were heated at $70^{\circ} \mathrm{C}$ for 15 minutes in $1 \mathrm{M} \mathrm{HCl}$, followed by 45 minutes in $1 \mathrm{M} \mathrm{KOH}$, and finally 15 minutes in $1 \mathrm{M} \mathrm{HCl}$. Following this pretreatment, samples were stored in $0.1 \mathrm{M} \mathrm{HCl}$ in glass vials with teflonlined screw caps. ${ }^{14} \mathrm{C}$ analyses were conducted at the Center for Accelerator Mass Spectrometry (CAMS) at Lawrence Livermore National Laboratory. ${ }^{14} \mathrm{C}$ ages were determined assuming $\delta^{13} \mathrm{C}$ values of $-25 \%$ (Stuiver and Polach, 1977), and the dates were converted to calibrated (cal) ages using OxCal 3.9 (Bronk Ramsey, 1995, 2001).

\section{Data analysis}

We used a subroutine in CALIB 4.3 (Stuiver and Reimer, 1993) to test for statistically significant $(\mathrm{p}<0.05)$ age differences between subsamples from a given depth. The subroutine determines the pooled average (weighted mean) of the ${ }^{14} \mathrm{C}$ dates, calculates the test statistic $T$ from the weighted sum of the differences between each sample age and the pooled average, and compares $T$ to a chi-square distribution for $n-1$ samples. If $T$ is less than the chi-square value, the dates do not differ statistically (Ward and Wilson, 1978). However, some samples have such large age uncertainties that this test may indicate that they are statistically equivalent even if they differ by several hundred years. The level of acceptable chronological uncertainty depends on the objective of the research; in this case, we limit our analyses to dates with uncertainties less than $250{ }^{14} \mathrm{C}$ years. We used a subroutine in OxCal 3.9 to determine the age difference ( $2 \delta$ cal year range) between those samples with statistically different ages.

\section{RESULTS}

\section{Sample-mass experiments}

${ }^{14} \mathrm{C}$ analyses of different-sized pieces of the same woody macrofossil returned statistically equivalent $(\mathrm{p}<0.05)$ dates for samples from UC 310-311, MK 121-122, AH 32-33, and VP 48-50 (Table 2). Radiocarbon ages were significantly different for dates 
on the subsamples of two macrofossils from MK 85-86 (Fig. 3). For sample MK 85-86 (a), the two ages differed by $1560-3810(2 \delta)$ cal $\left(1330 \pm 510{ }^{14} \mathrm{C}\right)$ years. For sample MK $85-86$ (b) the dates for the two largest samples were identical $(\sim 3600 \pm 2 \delta$ cal years, 3320 ${ }^{14} \mathrm{C}$ years $)$, but the small $(0.02 \mathrm{mg} \mathrm{C})$ and very small $(0.01 \mathrm{mg} \mathrm{C})$ samples were $360-3650$ cal $\left(910 \pm 760{ }^{14} \mathrm{C}\right)$ years younger and $1290-5850 \mathrm{cal}\left(1870 \pm 1160{ }^{14} \mathrm{C}\right)$ years older than this date, respectively. The dates for VP 26-28 (Fig. 3) were statistically equivalent, but the two smallest subsamples (mass $<0.04 \mathrm{mg} \mathrm{C}$ ) had unacceptable uncertainties (280 and $550{ }^{14} \mathrm{C}$ years).

\section{Sample-type experiments}

Based on the findings of the sample-mass experiments, samples $<0.05 \mathrm{mg} \mathrm{C}$ were excluded from the macrofossil-type analyses (Tables 3-5). For the remaining experiments, ${ }^{14} \mathrm{C}$ dates obtained for all different macrofossil types were statistically equivalent in only one case (RG 202-203), whereas at least one date was significantly different in the other eight cases (Fig. 4). For UC 155-157, graminoid leaf fragments dated at least $1950-3310 \mathrm{cal}\left(1530 \pm 310{ }^{14} \mathrm{C}\right)$ years older than the other materials, and for UC $250-251$, graminoid and moss dates differed by $10-1310 \mathrm{cal}\left(270 \pm 210{ }^{14} \mathrm{C}\right)$ years. For UC 310-311, six of the seven dates (including the three dates on different-sized pieces of the same woody macrofossil) did not differ statistically. The date for moss fragments, however, was younger by at least $140-2620 \mathrm{cal}\left(440 \pm 310{ }^{14} \mathrm{C}\right)$ years. For GY 39-40, five macrofossils had statistically equivalent ages, but the date for charcoal was at least $1410-1900 \mathrm{cal}\left(1500 \pm 100{ }^{14} \mathrm{C}\right)$ years older. Similarly, four of the ages from GY 133-135 were not statistically different, but wood and charcoal macrofossils were older by at least $760-1490$ and $930-1590 \mathrm{cal}\left(575 \pm 120\right.$ and $\left.730 \pm 110{ }^{14} \mathrm{C}\right)$ years, respectively. For GY 292-293, the dates from three different pieces of wood differed by as much as $490-1070 \mathrm{cal}\left(520 \pm 130{ }^{14} \mathrm{C}\right)$ years. In the OK $478-479$ experiment, the wood fragment was $550-1300 \mathrm{cal}\left(430 \pm 130{ }^{14} \mathrm{C}\right)$ years older than the moss macrofossil, and for AH 31-32, the seed had the youngest date, the moss fragments were 120-1930 cal $\left(400 \pm 310{ }^{14} \mathrm{C}\right)$ years older than the seed, and the wood macrofossils were 150-1480 and $3190-4710$ cal $\left(310 \pm 190\right.$ and $\left.2310 \pm 200{ }^{14} \mathrm{C}\right)$ years older than the moss. 


\section{DISCUSSION}

$\underline{\text { Sample-mass experiments }}$

The finding that ${ }^{14} \mathrm{C}$ dates for $>0.05 \mathrm{mg} \mathrm{C}$ pieces of the same macrofossil did not differ significantly suggests that $0.05 \mathrm{mg} \mathrm{C}$ is the sample-mass threshold for reliable age determination, given the procedures used in this study. These results are consistent with a study by Brown and Southon (1997) in which they observed larger-than-expected scatter in measured values for subsamples smaller than $\sim 0.03 \mathrm{mg} \mathrm{C}$ from a $6130 \pm 20{ }^{14} \mathrm{C}$ years BP sample (Stuiver and Becker, 1993; Brown, 1994). Two analytical factors likely contribute to our findings. First, in our procedures the completeness of the graphitization reaction during sample preparation is uncertain when the samples are very small. Studies of the graphitization process for larger samples show that fractionation occurs during the catalytic reactions of the gaseous constituents (primarily $\mathrm{CO}_{2}$ and $\mathrm{CO}$ ), with the isotopic content of the produced graphite reaching that of the initial $\mathrm{CO}_{2}$ sample as the reaction goes to completion (e.g., Aerts-Bijma et al., 1997). The fractionation observed between the initial $\mathrm{CO}_{2} \delta^{13} \mathrm{C}$ values and those of the last $\mathrm{CO}_{2}$ fraction remaining just before the reaction goes to completion $\left(\sim 30 \%\right.$ ) indicates that ${ }^{14} \mathrm{C}$ fractionations of up to $\sim-60 \%$ may occur due to incomplete graphitization. Thus, incomplete graphitization of small samples could result in measured ${ }^{14} \mathrm{C}$ ages being up to $\sim 500$ years older than the actual age of the sample. Second, with decreasing sample mass, any background contaminant carbon introduced during sample processing represents a greater fraction of the total sample. Hence, as sample mass decreases, variations in background contamination have an increasingly larger impact on background corrections of the ${ }^{14} \mathrm{C}$ measurements. Recent graphitization tests at CAMS (T.A. Brown, unpublished data) have shown that the ${ }^{14} \mathrm{C}$ content of background contaminants is consistent with current atmospheric $\mathrm{CO}_{2}$ values, such that inadvertent introduction of higher-than-normal amounts of such contaminants should result in measured ${ }^{14} \mathrm{C}$ ages being somewhat younger than the actual age of the sample. The increased significance of background contaminant corrections with decreasing sample mass and the larger-than-expected scatter of results obtained for very small samples suggest that larger-than-expected variations are occurring in the background contaminant when sample mass is below some threshold (Brown and Southon, 1997). In addition to these two factors, unusual isotopic fractionation effects in 
the AMS ion source and introduction of unusual contamination during graphite handling and/or target preparation also may contribute to the unexpectedly large scatter of the very small samples. As shown by Brown and Southon (1997) and by subsequent ongoing tests at CAMS (T.A. Brown, unpublished data), measurements of modern standard materials show similarly larger-than-expected scatter of ${ }^{14} \mathrm{C}$ ages for samples below a sample threshold of several 10s of $\mu \mathrm{g}$ carbon. Thus, while the exact cause of the apparent small sample threshold is not known at present, the $0.05 \mathrm{mg} \mathrm{C}$ threshold found in this study is consistent with results of Brown and Southon (1997) and with more recent tests conducted within the CAMS graphitization laboratories.

\section{Sample-type experiments}

The results of the sample-type experiments are of concern to current dating procedures for northern lake sediments. In many cases, different types of macrofossil from the same core depth differed by more than $500{ }^{14} \mathrm{C}$ years. A number of factors may contribute to these age discrepancies, including (1) carbon source or fractionation differences between plants, (2) the slow sedimentation rates of these lakes, (3) taphonomic or "in-built age" differences among macrofossil types, and (4) differences in susceptibility to contamination. We consider each factor in more detail below.

\section{Carbon source or fractionation}

If plants obtain carbon directly from lake water in carbonate terrain, macrofossil ${ }^{14} \mathrm{C}$ ages might appear too old as the result of a reservoir effect (e.g., Deevey et al., 1954). For example, MacDonald et al. (1987) found that ${ }^{14} \mathrm{C}$ ages of aquatic moss macrofossils from western Canada were $>1500$ years older than their terrestrial counterparts. Although we did not differentiate between terrestrial and aquatic mosses, moss macrofossils never had the greatest ages in the type experiments, suggesting carbon equilibration with the atmosphere, as would be the case for other plant types. In addition to possible carbonsource effects, age discrepancies might also result from differences in ${ }^{14} \mathrm{C}$ fractionation among plant species (Aitken, 1993). Differences in ${ }^{14} \mathrm{C}$ depletion can be accounted for by adjusting ${ }^{14} \mathrm{C}$ values relative to measured ${ }^{13} \mathrm{C}$ values (Craig, 1953) or by calculations assuming an expected $\delta^{13} \mathrm{C}$ value. In this study, ${ }^{14} \mathrm{C}$ dates were calculated assuming $\delta^{13} \mathrm{C}$ 
values of $-25 \%$ (Stuiver and Polach, 1977), which is almost certainly within 5\%o of the actual $\delta^{13} \mathrm{C}$ value of a terrestrial macrofossil, and within $\sim 9 \%$ of that of an aquatic macrofossil (Gupta and Polach, 1985; Aitken, 1993). Because the AMS measurements were of the ${ }^{14} \mathrm{C} /{ }^{13} \mathrm{C}$ atom ratio of the samples, a $\delta^{13} \mathrm{C}$ departure from $-25 \%$ of $1 \%$ would correspond to a ${ }^{14} \mathrm{C}$ age shift of roughly 8 years, and hence the fractionation correction for these dates would be at most 40 years for terrestrial samples and $\sim 80$ years for aquatic samples. Because this adjustment is smaller than the observed age disparities $(>650 \pm 2 \delta$ cal years), the fractionation effect is not likely to be the main cause of the ${ }^{14} \mathrm{C}$ differences among macrofossils from the same core depth.

\section{Time-span of the sample}

The slow sedimentation rates of the study lakes could potentially result in the accumulation of macrofossils of widely different ages in a 1-2 cm thick section of the core. To test the importance of this effect, we compared the age discrepancies for the Upper Capsule and Grizzly sample-type experiments with estimates of the time-span of each sample (Table 6). The time elapsed per sample (always $<80$ cal years) was substantially less than the age difference between macrofossils (always $>650 \pm 2 \delta$ cal years). Thus, slow sedimentation does not appear to account for the age discrepancies. On the other hand, the samples from MK 85-86 illustrate the difficulty in dating sediments that have accumulated irregularly. The overall age-depth relationship for the Malyii Kretchet record (Fig. 5) is complicated by an interval of peat (60-87 cm), within which macrofossils of substantially different age occur at the same depth. Assuming that the four MK 85-86 samples $<0.05 \mathrm{mg} \mathrm{C}$ may have erroneous ages (Fig. 3), whereas the ages of the two samples $>0.05 \mathrm{mg} \mathrm{C}$ are likely reliable, it would appear that this $1-\mathrm{cm}$ thick interval contains macrofossils differing by at least $1550-2950 \mathrm{cal}\left(1180 \pm 300{ }^{14} \mathrm{C}\right)$ years.

\section{Taphonomy or in-built age}

Age discrepancies might also result from differences in taphonomy or "in-built age" among macrofossil types. The most striking result of the sample-type experiments is that wood and charcoal are generally older than other macrofossils from the same sample 
depth. The amount of the offset was inconsistent, with age differences ranging from tens to thousands of years, but this trend occurred in all but one of the experiments (UC 155157 ) in which wood or charcoal was dated. Because woody macrofossils are relatively large and decay-resistant (Hobbie, 1996), they are likely to remain on the landscape longer than smaller, more readily decomposed plant tissues. In addition, dates on wood and charcoal might be older due to an "in-built age" effect (e.g., McFadgen, 1982; Gavin, 2001). Because woody plants maintain old tissues in their structure, wood in the inner rings of a branch or stem could be substantially older than the outermost layers. Thus, even if the remains of a woody plant were washed into a lake as soon as the plant died, a

${ }^{14} \mathrm{C}$ date on a piece of wood might appear significantly older than the rest of the sediment if the dated tissues came from the inner rings. This type of error should be less important in tundra than in boreal forest ecosystems, as woody tundra plants have been observed to reach 30-55 years in age (Warren Wilson, 1964; Shaver, 1986), whereas boreal forest trees in interior Alaska often live beyond 250 years (e.g., Van Cleve et al., 1983).

\section{Contamination}

Another explanation for the tendency of woody samples to be older than non-woody materials is that some macrofossil types may be more susceptible to contamination than others. For example, woody tissues may have some propensity for contamination by old carbon, perhaps because of their rough surface texture. On the other hand, moss and leaf fragments could have younger ${ }^{14} \mathrm{C}$ dates than wood because they are more easily contaminated by modern carbon. These non-woody macrofossils are generally flat or filamentous, and therefore their surface area to volume ratio is larger than that of wood and charcoal pieces. Contamination by modern carbon is much more likely to have an important age effect than that by old carbon, as the substantially higher ${ }^{14} \mathrm{C}$ activity of young carbon creates a larger magnitude dating error than old carbon for the same amount of contaminant (Olsson, 1974). However, the sample pretreatment routine should remove impurities from the surface of the macrofossils, such that contamination by young or old carbon is avoided. 


\section{Environmental change}

A potentially important factor not addressed in depth by this study is the effect of environmental and ecological changes on the age of macrofossils relative to the lakesediment matrix. As sediment accumulates in a lake basin over time, environmental changes might affect the type or taphonomy of macrofossils that reach the lake and thus become available for dating. For example, the Grizzly pollen record indicates an early Holocene change from Betula-Populus stands to Picea glauca forest, and a subsequent transition to Picea mariana (W. Tinner, unpublished data). The first change might affect the ${ }^{14} \mathrm{C}$ chronology of the sediments by altering the type of woody material entering the lake, whereas the second change reduced the rate of soil erosion and thus may have slowed the delivery of macrofossils to the coring site. Similarly, the Upper Capsule pollen record indicates ecological changes between the early and middle Holocene, including higher overall vegetation cover, increased woody shrub prevalence, and slower decomposition (Oswald et al., 2003). This transition also has implications for ${ }^{14} \mathrm{C}$ dating because the change in plant community composition would have increased the availability of woody macrofossils, whereas the change in decomposition would have increased the terrestrial residence time of plant macrofossils. It would be necessary to analyze a greater number of macrofossils and sampling depths to begin to assess the effect of these types of environmental and ecological change.

\section{CONCLUSIONS}

The results of this study provide insights for dating lake sediments from the northernmost latitudes, but they are also relevant to the general use of ${ }^{14} \mathrm{C}$ analysis in Quaternary sciences. The sample-mass experiments demonstrate that these laboratory and analytical procedures can be used to obtain statistically equivalent ${ }^{14} \mathrm{C}$ dates for lake-sediment macrofossils as small as $0.05 \mathrm{mg} \mathrm{C}$. The ability to date such small materials is crucial for understanding the chronology of macrofossil-poor sediments, including those from many northern lakes, as well as other scenarios where only very small amounts of organic matter are available for dating (e.g., large lakes, glacial-age sediments). However, the experiments involving ${ }^{14} \mathrm{C}$ analysis of different plant tissues from the same sediment depth suggest that some macrofossil types may provide erroneous deposition ages. Wood 
and charcoal were generally older than other types of plant remains, and in several cases the dates for these materials exceeded other dates by several hundred years. We attribute this pattern to the slower decomposition and longer terrestrial residence time of woody macrofossils in arctic and boreal environments, and perhaps to the "in-built age" effect that may occur in ecosystems with long-lived plants.

Because woody macrofossils are commonly selected for ${ }^{14} \mathrm{C}$ dating (e.g., Oswald et al., 1999; Anderson and Lozhkin, 2001; Lozhkin et al., 2001), the conclusion that they may not provide accurate dates for lake-sediment paleoenvironmental records is important. If the research objective is to reconstruct past changes at the scale of centuries or decades, as is increasingly the case (e.g., Hu et al., 2001), an error of several hundred years is unacceptable. This type of age bias is not only a potential problem in the northernmost latitudes, but also in mid-latitude regions where intervals of the past were characterized by cold conditions and permafrost. Fortunately, we can use the results of this study and other ${ }^{14} \mathrm{C}$ dating experiments (e.g., Turney et al., 2000; Nilsson et al., 2001) to guide the selection of samples so that the risk of problematic dates is minimized.

\section{ACKNOWLEDGEMENTS}

This research was funded by the U.S. National Science Foundation, the National Geographic Society, and the Russian Foundation for Fundamental Research (grant number 03-05-64294), and was performed in part under the auspices of the U.S. Department of Energy by the University of California, Lawrence Livermore National Laboratory, under contract W-7405-ENG-48. We thank Patricia Gomez and Kailen Mooney for laboratory assistance. Previous and current versions of this manuscript benefited greatly from thoughtful reviews by Alan Gillespie, Gifford Miller, and three anonymous referees. This is contribution 193 from the Paleoenvironmental Arctic Sciences (PARCS) program.

\section{REFERENCES}

Abbott, M.B., and Stafford, T.W., Jr. 1996: Radiocarbon geochemistry of modern and ancient arctic lake systems, Baffin Island, Canada. Quaternary Research 45, 300-311. 
Aerts-Bijma, A.T., Meijer, H.A.J., and van der Plicht, J. 1997: AMS sample handling in Groningen. Nuclear Instruments and Methods in Physics Research B 123, 221-225. Aitken, M.J. 1993: Science-based Dating in Archaeology. Longman, London.

Allen, J.R.M., Brandt, U., Brauer, A., Hubberten, H.W., Huntley, B., Keller, J., Kraml, M., Mackensen, A., Mingram., J., Negendank, J.F.W., Nowaczyk, N.R., Oberhansli, H., Watts, W.A., Wulf, S., and Zolitschka, B. 1999: Rapid environmental changes in southern Europe during the last glacial period. Nature 400, 740-743.

Anderson, P.M. and Lozhkin, A.V. 2001: The Stage 3 interstadial complex (Karginskii/middle Wisconsinan interval) of Beringia: variations in paleoenvironments and implications for paleoclimatic interpretations. Quaternary Science Reviews 20, 93-126.

Andreev, A.A., Klimanov, V.A., and Sulerzhitsky, L.D. 2001: Vegetation and climate history of the Yana River lowland, Russia, during the last 6400 yr. Quaternary Science Reviews 20, 259-266.

Bigelow, N.H. and Edwards, M.E. 2001: A 14,000 yr paleoenvironmental record from Windmill Lake, central Alaska: Lateglacial and Holocene vegetation in the Alaska Range. Quaternary Science Reviews 20, 203-215.

Bockheim, J.G., Walker, D.A., Everett, L.R., Nelson, F.E., and Shiklomanov, N.I. 1998: Soils and cryoturbation in moist nonacidic and acidic tundra in the Kuparuk River Basin, arctic Alaska, U.S.A. Arctic and Alpine Research 30, 166-174.

Bronk Ramsey, C. 1995: Radiocarbon calibration and analysis of stratigraphy: the OxCal program. Radiocarbon 37, 425-430.

Bronk Ramsey, C. 2001: Development of the radiocarbon program OxCal. Radiocarbon 43, 355-363.

Brown, T.A. 1994: Radiocarbon dating of pollen by accelerator mass spectrometry. Ph.D. thesis, University of Washington, Seattle.

Brown, T.A. and Southon, J.R. 1997: Corrections for contamination background in AMS ${ }^{14} \mathrm{C}$ measurements. Nuclear Instruments and Methods in Physics Research B 123, 208-213. 
Brubaker, L.B., Anderson, P.M., and Hu, F.S. 2001: Vegetation ecotone dynamics in Southwest Alaska during the Late Quaternary. Quaternary Science Reviews 20, 175189.

Clark, J.S., Grimm, E.C., Donovan, J.J., Fritz, S.C., Engstrom, D.R., and Almendinger, J.E. 2002: Drought cycles and landscape responses to past aridity on prairies on the northern Great Plains, USA. Ecology 83, 595-601.

Craig, H. 1953: The geochemistry of the stable carbon isotopes. Geochimica et Cosmochimica Acta 3, 53-92.

Cwynar, L.C. and Watts, W.A. 1989: Accelerator mass spectrometer ages for Late-glacial events at Ballybetagh, Ireland. Quaternary Research 31, 377-380.

Deevey, E.S., Jr., Gross, M.S., Hutchinson, G.E., and Kraybill, H.L. 1954: The natural C14 contents of materials from hard-water lakes. Proceedings of the National Academy of Sciences 40, 285-288.

Gavin, D.G. 2001: Estimation of inbuilt age in radiocarbon ages of soil charcoal for fire history studies. Radiocarbon 43, 27-44.

Gupta, S.K. and Polach, H.A. 1985: Radiocarbon dating practices at ANU. Research School of Pacific Studies, Australian National University, Canberra.

Hobbie, S. 1996: Temperature and plant species control over litter decomposition in Alaskan tundra. Ecological Monographs 66, 503-522.

Hu, F.S., Brubaker, L.B., and Anderson, P.M. 1996: Boreal ecosystem development in the northwestern Alaska Range since 11,000 yr B.P. Quaternary Research 45, 188201.

Hu, F.S., Ito, E., Brown, T.A., Curry, B.B., and Engstrom, D.R. 2001: Pronounced climatic variations in Alaska during the last two millenia. Proceedings of the National Academy of Sciences 98, 10552-10556.

Hua, Q., Jacobsen, G.E., Zoppi, U., Lawson, E.M., Williams, A.A., Smith, A.M., and McGann, M.J. 2001: Progress in radiocarbon target preparation at the ANTARES AMS Centre. Radiocarbon 43, 275-282.

Kirner, D.L., Southon, J., Hare, P.E., and Taylor, R.E. 1996: Accelerator mass spectrometry radiocarbon measurement of submilligram samples. Archaeological Chemistry 625, 434-442. 
Lozhkin, A.V., Anderson, P.M., Vartanyan, S.L., Brown, T.A., Belaya, B.V., and Kotov, A.N. 2001: Late Quaternary paleoenvironments and modern pollen data from Wrangel Island (Northern Chukotka). Quaternary Science Reviews 20, 217-234.

Mann, D.H., Heiser, P.A., and Finney, B.P. 2002: Holocene history of the Great Kobuk Sand Dunes, Northwestern Alaska. Quaternary Science Reviews 21, 709-731.

MacDonald, G.M., Beukens, R.P., Kieser, W.E., and Vitt, D.H. 1987: Comparative radiocarbon dating of terrestrial plant macrofossils and aquatic moss from the "icefree corridor" of western Canada. Geology 15, 837-840.

McFadgen, B.G. 1982: Dating New Zealand archaeology by radiocarbon. New Zealand Journal of Science 25, 379-392.

Miller, G.H., Mode, W.N., Wolfe, A.P., Sauer, P.E., Bennike, O., Forman, S.L., Short, S.K., and Stafford, T.W., Jr. 1999: Stratified interglacial lacustrine sediments from Baffin Island, Arctic Canada: chronology and paleoenvironmental implications. Quaternary Science Reviews 18, 789-810.

Muller, S.V., Racoviteanu, A.E., and Walker, D.A. 1999: Landsat MSS-derived landcover map of northern Alaska: extrapolation methods and a comparison with photointerpreted and AVHRR-derived maps. International Journal of Remote Sensing 20, 2921-2946.

Nelson, R.E., Carter, L.D., and Robinson, S.W. 1988: Anomalous radiocarbon dates from a Holocene detrital lens in Alaska and their implications for radiocarbon dating and paleoenvironmental reconstruction in the Arctic. Quaternary Research 29, 66-71.

Newnham, R.M. and Lowe, D.J. 2000: Fine-resolution pollen record of late-glacial climate reversal from New Zealand. Geology 28, 759-762.

Nilsson, M., Klarqvist, M., Bohlin, E., and Possnert, G. 2001: Variation in ${ }^{14} \mathrm{C}$ age of macrofossils and different fractions of minute peat samples dated by AMS. The Holocene 11, 579-586.

Olsson, I.U. 1974: Some problems in connection with the evaluation of ${ }^{14} \mathrm{C}$ dates. Geologiska Föreningens I Stockholm Förhandlingar 96, 311-320.

Oswald, W.W., Brubaker, L.B., and Anderson, P.M. 1999: Late Quaternary vegetational history of the Howard Pass area, northwestern Alaska. Canadian Journal of Botany 77, 570-581. 
Oswald, W.W., Brubaker, L.B., Hu, F.S., and Kling, G.W. 2003: Holocene pollen records from the central Arctic Foothills, northern Alaska: testing the role of substrate in the response of tundra to climate change. Journal of Ecology 91, 1034-1048.

Sarnthein, M., Kennett, J.P., Chappell, J., Crowley, T., Curry, W., Duplessy, J.C., Grootes, P., Hendy, I., Laj, C., Negendank, J., Schulz, M., Shackleton, N.J., Voelker, A., and Zolitschka, B. 2000: Exploring late Pleistocene climate variations. Eos 81, 625-640.

Shaver, G.R. 1986: Woody stem production in Alaskan tundra shrubs. Ecology 67, 660669.

Stuiver, M. and Becker, B. 1993: High-precision decadal calibration of the radiocarbon time scale, AD 1950-6000 BC. Radiocarbon 35, 35-65.

Stuiver, M. and Polach, H. 1977: Discussion: reporting of ${ }^{14} \mathrm{C}$ data. Radiocarbon 19, 355363.

Stuiver, M. and Reimer, P.J. 1993: Extended ${ }^{14} \mathrm{C}$ database and revised CALIB radiocarbon calibration program. Radiocarbon 35, 215-230.

Törnqvist, T.E., de Jong, A.F.M., Oosterbaan, W.A., and van der Borg, K. 1992: Accurate dating of organic deposits by AMS ${ }^{14} \mathrm{C}$ measurement of macrofossils. Radiocarbon 34, 566-577.

Turney, C.S.M., Coope, G.R., Harkness, D.D., Lowe, J.J., and Walker, M.J.C. 2000: Implications for the dating of Wisconsinan (Weichselian) late-glacial events of systematic radiocarbon age differences between terrestrial plant macrofossils from a site in SW Ireland. Quaternary Research 53, 114-121.

Van Cleve, Dyrness, C.T., Viereck, L.A., Fox, J., Chapin, F.S., III., and Oechel, W. 1983: Taiga ecosystems in interior Alaska. BioScience 33, 39-44.

Von Reden, K.F., McNichol, A.P., Pearson, A., and Schneider, R.J. 1998: ${ }^{14}$ C AMS measurements of $<100 \mu \mathrm{g}$ samples with a high-current system. Radiocarbon 40, 247253.

Walker, D.A., Bockheim, J.G., Chapin, III, F.S., Nelson, F.E., and Ping, C.L. 2001: Calcium-rich tundra, wildlife, and the Mammoth Steppe. Quaternary Science Reviews 20, 149-163. 
Walker, M.D., Walker, D.A., and Auerbach, A.N. 1994: Plant communities of a tussock tundra landscape in the Brooks Range Foothills, Alaska. Journal of Vegetation Science 5, 843-866.

Ward, G.K. and Wilson, S.R. 1978: Procedures for comparing and combining radiocarbon age determinations: A critique. Archaeometry 20, 19-31.

Warren Wilson, J. 1964: Annual growth of Salix arctica in the High-Arctic. Annals of Botany 28, 71-76.

Western Regional Climate Center 2002: Western U.S. Climate Historical Summaries (www.wrcc.dri.edu).

Wright, H.E., Jr., Mann, D.H., Glaser, P.H. 1984: Piston corers for peat and lake sediments. Ecology 65, 657-659.

Zhang, T., Osterkamp, T.E., and Stamnes, K. 1996: Some characteristics of climate in northern Alaska, U.S.A. Arctic and Alpine Research 28, 509-518.

Zimov, S.A., Voropaev, Y.V., Semiletov, I.P., Davidov, S.P., Prosiannikov, S.F., Chapin, F.S., Chapin, M.C., Trumbore, S., and Tyler, S. 1997: North Siberian lakes: a methane source fueled by Pleistocene carbon. Science 277, 800-802. 
Table 1. Study sites

\begin{tabular}{lllll}
\hline Site & Code & Location & Region & Vegetation \\
\hline Grizzly & GY & $62^{\circ} 43^{\prime} \mathrm{N}, 144^{\circ} 12^{\prime} \mathrm{W}$ & Copper River, Alaska & Picea boreal forest \\
Upper Capsule & UC & $68^{\circ} 38^{\prime} \mathrm{N}, 149^{\circ} 25^{\prime} \mathrm{W}$ & North Slope, Alaska & Moist dwarf-shrub tussock graminoid tundra \\
Red Green & RG & $68^{\circ} 39^{\prime} \mathrm{N}, 149^{\circ} 41^{\prime} \mathrm{W}$ & North Slope, Alaska & Moist graminoid prostrate-shrub tundra \\
Okpilak & OK & $69^{\circ} 25^{\prime} \mathrm{N}, 144^{\circ} 02^{\prime} \mathrm{W}$ & North Slope, Alaska & Moist graminoid prostrate-shrub tundra \\
Ahaliorak & AH & $68^{\circ} 55^{\prime} \mathrm{N}, 151^{\circ} 20^{\prime} \mathrm{W}$ & North Slope, Alaska & Moist dwarf-shrub tussock graminoid tundra \\
Vadopadnoye & VP & $59^{\circ} 24^{\prime} \mathrm{N}, 150^{\circ} 39^{\prime} \mathrm{E}$ & Priokhot'ye, Russia & Larix dahurica forest \\
Malyii Kretchet & MK & $64^{\circ} 28^{\prime} \mathrm{N}, 175^{\circ} 19^{\prime} \mathrm{E}$ & Anadyr Basin, Chukotka, Russia & Pinus pumila-Alnus shrub tundra \\
\hline
\end{tabular}


Table 2. Sample-mass experiments

\begin{tabular}{llrlrr}
\hline Sample & Material & Mass $(m g$ C) & CAMS No. & \multicolumn{1}{c}{ C age BP } & $2 \delta$ cal ${ }^{14}$ C age range \\
\hline AH 32-33 & Wood & 0.05 & 66731 & $9350 \pm 180$ & $11168-10187$ \\
& Wood & 0.35 & 66732 & $9280 \pm 50$ & $10636-10245$ \\
MK 85-86 (a) & Wood & 1.03 & 66733 & $9320 \pm 40$ & $10670-10400$ \\
& Wood & 0.03 & 48500 & $3170 \pm 240$ & $3932-2778$ \\
MK 85-86 (b) $)$ & Wood & 0.11 & 48499 & $4500 \pm 90$ & $5451-4860$ \\
& Wood & 0.01 & 48504 & $5190 \pm 550$ & $7248-4570$ \\
& Wood & 0.02 & 48503 & $2410 \pm 330$ & $3269-1692$ \\
MK 121-122 & Wood & 0.04 & 48502 & $3320 \pm 190$ & $4080-3137$ \\
& Wood & 0.07 & 48501 & $3320 \pm 120$ & $3838-3328$ \\
& Wood & 0.12 & 66729 & $8370 \pm 80$ & $9530-9132$ \\
VP 26-28 & Wood & 0.50 & 66730 & $8230 \pm 40$ & $9400-9031$ \\
& Wood & 0.96 & 66750 & $8300 \pm 60$ & $9473-9090$ \\
& Wood & 0.01 & 49702 & $2330 \pm 550$ & $3646-1172$ \\
& Wood & 0.03 & 49701 & $2830 \pm 280$ & $3637-2330$ \\
& Wood & 0.06 & 49698 & $2990 \pm 130$ & $3469-2787$ \\
& Wood & 0.07 & 49697 & $2990 \pm 120$ & $3466-2848$ \\
& Wood & 0.07 & 49699 & $3040 \pm 120$ & $3474-2874$ \\
VP 48-50 & 0.08 & 49696 & $3050 \pm 100$ & $3469-2952$ \\
& Wood & 0.10 & 49700 & $3000 \pm 90$ & $3386-2922$ \\
& Wood & 0.06 & 50792 & $4170 \pm 140$ & $5045-4299$ \\
& Wood & 0.08 & 50793 & $4180 \pm 110$ & $4971-4418$ \\
& Wood & 0.17 & 50794 & $4290 \pm 60$ & $5028-4654$ \\
& Wood & 0.22 & 50795 & $4270 \pm 60$ & $4968-4648$ \\
& Wood & 0.07 & 66734 & $9990 \pm 150$ & $12298-11162$ \\
& Wood & 0.13 & 66735 & $9830 \pm 90$ & $11549-11115$ \\
& Wood & 0.29 & 66736 & $10030 \pm 60$ & $12090-11255$ \\
\hline
\end{tabular}


Table 3. Upper Capsule Lake macrofossil-type experiments

\begin{tabular}{llrrrr}
\hline Sample & Material & Mass (mg C) & CAMS No. & ${ }^{14}$ C age BP & $2 \delta$ cal ${ }^{14}$ C age range \\
\hline UC 155-157 & Leaf fragments & 0.05 & 66741 & $3670 \pm 120$ & $4408-3688$ \\
& Graminoid leaf fragments & 0.05 & 66742 & $5250 \pm 130$ & $6296-5721$ \\
& Semi-woody fragments & 0.08 & 66743 & $3720 \pm 80$ & $4348-3836$ \\
UC 250-251 & Graminoid leaf fragments & 0.11 & 66745 & $8470 \pm 90$ & $9554-9278$ \\
& Moss & 1.09 & 66744 & $8200 \pm 50$ & $9399-9015$ \\
UC 310-311 & Moss & 0.08 & 66747 & $9270 \pm 120$ & $10745-10211$ \\
& Graminoid leaf fragments & 0.11 & 66749 & $9710 \pm 100$ & $11256-10735$ \\
& Seed & 0.07 & 66748 & $9920 \pm 150$ & $12099-11088$ \\
& Wood & 1.04 & 66746 & $10010 \pm 50$ & $11931-11255$ \\
\hline
\end{tabular}


Table 4. Grizzly Lake macrofossil-type experiments

\begin{tabular}{llrlrr}
\hline Sample & Material & Mass (mg C) & CAMS No. & ${ }^{14}$ C age BP & $2 \delta$ cal \\
\hline GY 39-40 & C age range \\
& Moss & 0.10 & 82319 & $100 \pm 70$ & $294-0$ \\
& Conifer periderm & 0.17 & 82318 & $95 \pm 45$ & $278-0$ \\
& Deciduous periderm & 0.30 & 82317 & $175 \pm 40$ & $300-0$ \\
& Wood & 0.32 & 82314 & $150 \pm 40$ & $291-0$ \\
& Picea needle & 0.37 & 82313 & $180 \pm 40$ & $302-0$ \\
GY 133-135 & Charcoal & 0.93 & 82316 & $1685 \pm 30$ & $1692-1524$ \\
& Picea conescale & 0.37 & 82322 & $4125 \pm 35$ & $4825-4526$ \\
& Moss & 0.42 & 82326 & $4160 \pm 40$ & $4832-4532$ \\
& Conifer periderm & 0.89 & 82325 & $4190 \pm 40$ & $4840-4573$ \\
& Picea needle & 0.94 & 82320 & $4225 \pm 40$ & $4855-4644$ \\
& Wood & 0.95 & 82321 & $4800 \pm 45$ & $5607-5334$ \\
& Charcoal & 0.97 & 82323 & $4955 \pm 40$ & $5842-5601$ \\
GY 292-293 & Weciduous periderm & 1.01 & 82324 & $4180 \pm 40$ & $4836-4571$ \\
& Wood & 0.94 & 59340 & $6910 \pm 40$ & $7819-7665$ \\
& Wood & 0.95 & 59339 & $7100 \pm 50$ & $8011-7792$ \\
& Charcoal & 0.99 & 59341 & $7430 \pm 50$ & $8362-8059$ \\
\hline
\end{tabular}


Table 5. Additional macrofossil-type experiments

\begin{tabular}{llrlrr}
\hline Sample & Material & Mass $(\mathrm{mg} \mathrm{C})$ & CAMS No. & ${ }^{14} \mathrm{C}$ age BP & $2 \delta$ cal \\
\hline AH 31-32 & Seed & 0.07 & 76814 & $8680 \pm 130$ & $10157-9471$ \\
& Moss & 0.14 & 76813 & $9080 \pm 80$ & $10471-9976$ \\
& Wood & 0.46 & 76812 & $9390 \pm 50$ & $10742-10430$ \\
& Wood & 1.00 & 44522 & $11390 \pm 60$ & $13791-13051$ \\
OK 478-479 & Seed & $0.02 *$ & 76817 & $6750 \pm 380$ & $8347-6848$ \\
& Moss & 0.26 & 76816 & $7660 \pm 50$ & $8541-8373$ \\
& Wood & 1.02 & 76815 & $8090 \pm 40$ & $9236-8988$ \\
RG 202-203 & Moss & $0.04^{*}$ & 66738 & $7140 \pm 220$ & $8387-7573$ \\
& Wood & 0.07 & 66739 & $7190 \pm 120$ & $8198-7755$ \\
& Leaf & 0.08 & 66737 & $7060 \pm 100$ & $8108-7674$ \\
\hline
\end{tabular}

*Samples $<0.05 \mathrm{mg} \mathrm{C}$ not included in analyses 
Table 6. Comparison of statistically significant age differences with the time elapsed per sample for the Upper Capsule and Grizzly macrofossil-type experiments.

\begin{tabular}{llr}
\hline Sample & Age difference (2 cal year range) & Years per sample* \\
\hline UC 155-157 & $1950-3310$ & 76.7 \\
UC 250-251 & $10-1310$ & 57.0 \\
UC 310-311 & $140-2620$ & 30.5 \\
GY 39-40 & $1410-1900$ & 22.8 \\
GY 133-135 & $760-1490,930-1590$ & 73.0 \\
GY 292-293 & $490-1070$ & 9.7 \\
\hline
\end{tabular}

*Based on age-depth relationships in Figure 2. 


\section{FIGURE CAPTIONS}

Figure 1. Map of Bering Strait region with locations of primary study sites (GY $=$ Grizzly, $\mathrm{UC}=$ Upper Capsule) and secondary study sites ( $\mathrm{VP}=$ Vadopadnoye, $\mathrm{MK}=$ Malyii Kretchet, $\mathrm{AH}=$ Ahaliorak, $\mathrm{RG}=$ Red Green, $\mathrm{OK}=$ Okpilak).

Figure 2. Age-depth plots for Grizzly and Upper Capsule. Bars indicate calibrated ${ }^{14} \mathrm{C}$

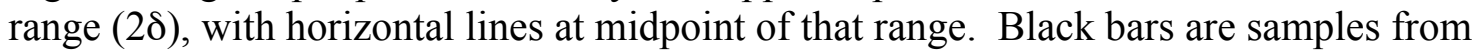
the mass and type experiments (Tables 2-4); gray bars are samples from other studies (Oswald et al., 2003; W. Tinner, unpublished data). Open box indicates the depth of the increase in Alnus pollen percentages in the Upper Capsule record, which dates to $\sim 7000$ cal years BP in records from nearby sites (Oswald et al., 1999, 2003). The samples at UC $100-101$ and UC $207-208 \mathrm{~cm}$ (not part of this study) presumably deviate from the agedepth relationship because of contamination by relatively young carbon. The dotted lines are drawn between selected dates to estimate the time elapsed per sample (Table 6) and to illustrate the overall age-depth relationship for the records.

Figure 3. Plots of calibrated ${ }^{14} \mathrm{C}$ age versus sample mass $(\mathrm{mg} \mathrm{C})$ for the Malyii Kretchet 85-86 (a), Malyii Kretchet 85-86 (b), and Vadopadnoye 26-28 experiments. Bars indicate calibrated ${ }^{14} \mathrm{C}$ range $(2 \delta)$.

Figure 4. Plots of calibrated ${ }^{14} \mathrm{C}$ ages for the macrofossil-type experiments (Tables 3-5). Bars indicate calibrated ${ }^{14} \mathrm{C}$ range (2 $\delta$ ). Black bars are woody macrofossils (wood and charcoal); gray bars are other types. Codes for macrofossil types: $\mathrm{W}=$ wood or charcoal, $\mathrm{C}=$ conescale, $\mathrm{G}=$ graminoid, $\mathrm{L}=$ leaf, $\mathrm{M}=$ moss, $\mathrm{N}=$ needle, $\mathrm{P}=$ periderm, $\mathrm{S}=$ seed.

Figure 5. Age-depth plot for Malyii Kretchet. Bars indicate calibrated ${ }^{14} \mathrm{C}$ range $(2 \delta)$, with horizontal lines at midpoint of that range. Black bars are samples from the mass experiment (Table 2); gray bars are samples from another study (P.M. Anderson, unpublished data). The interval of peat between 60 and $87 \mathrm{~cm}$ presumably was deposited during a period of lowered lake level. 


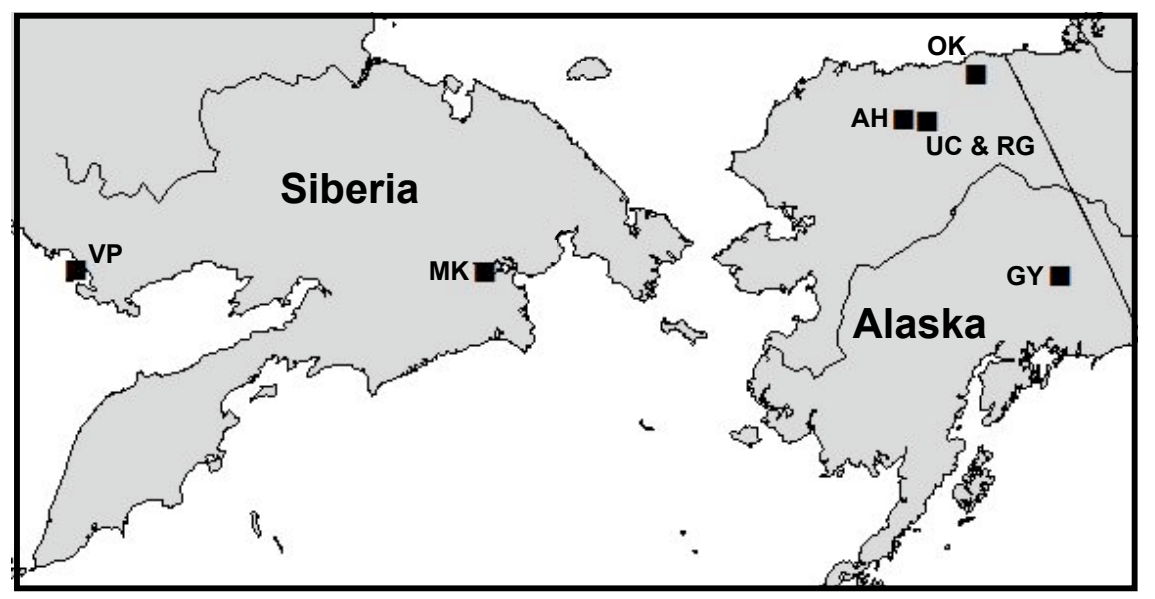

Figure 1. Oswald et al. 

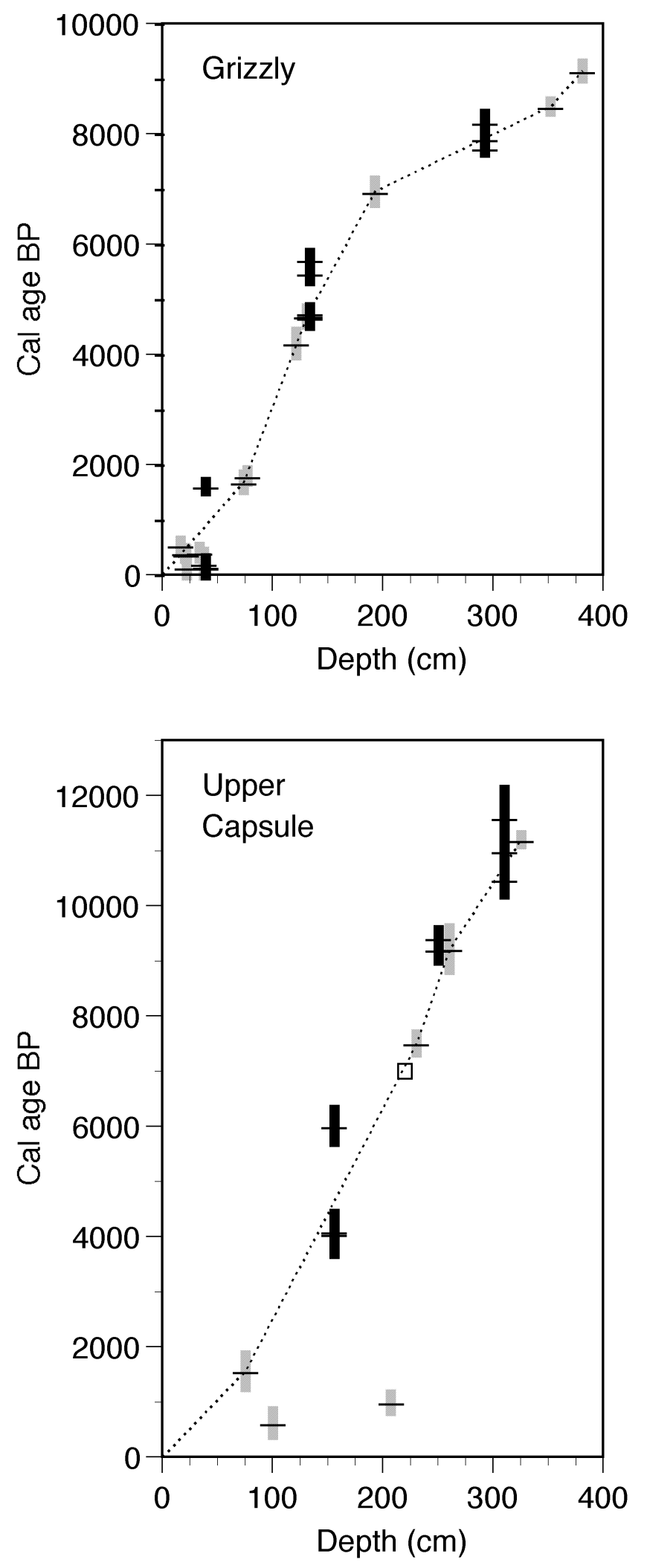

Figure 2. Oswald et al. 

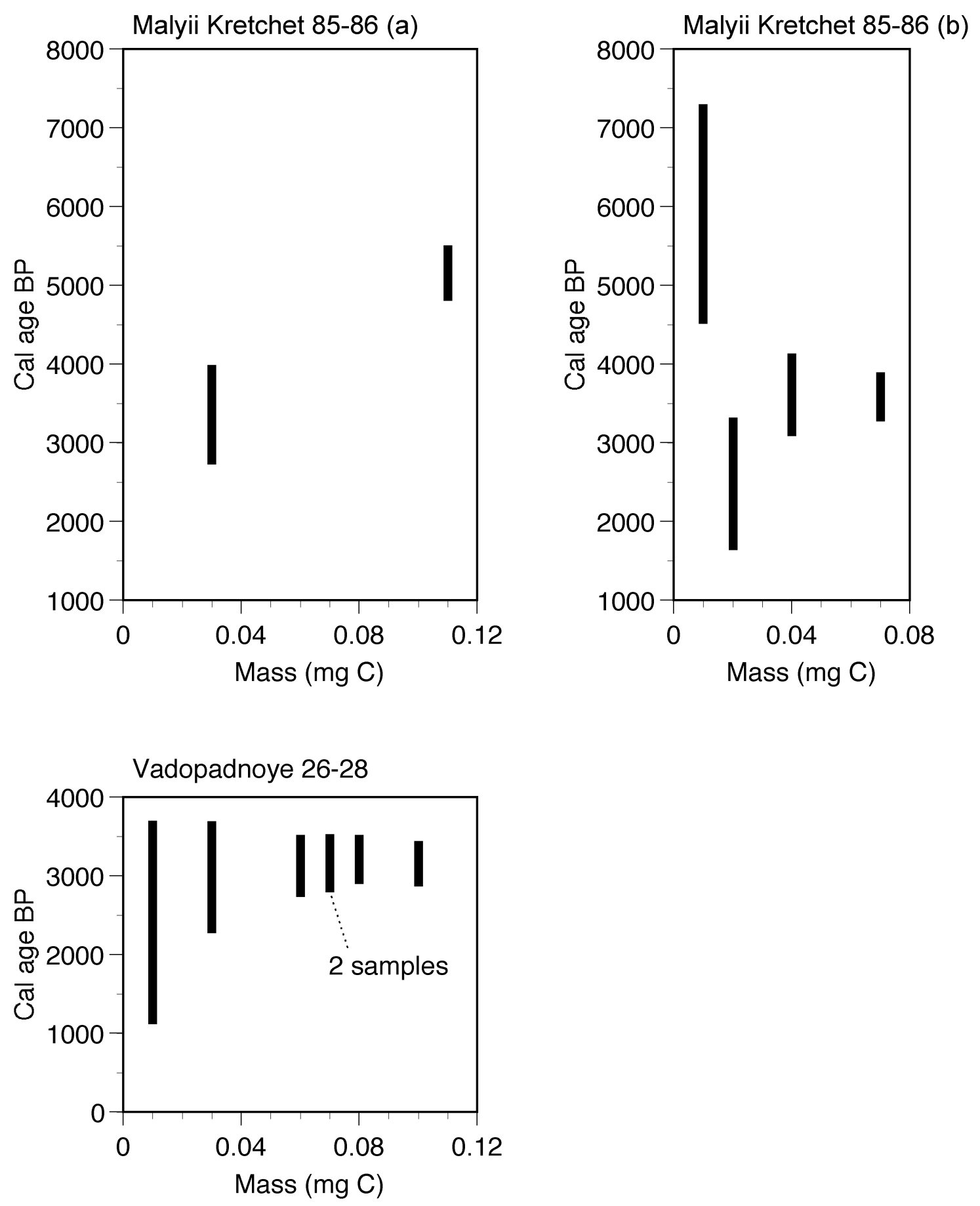

Figure 3. Oswald et al. 
Upper Capsule
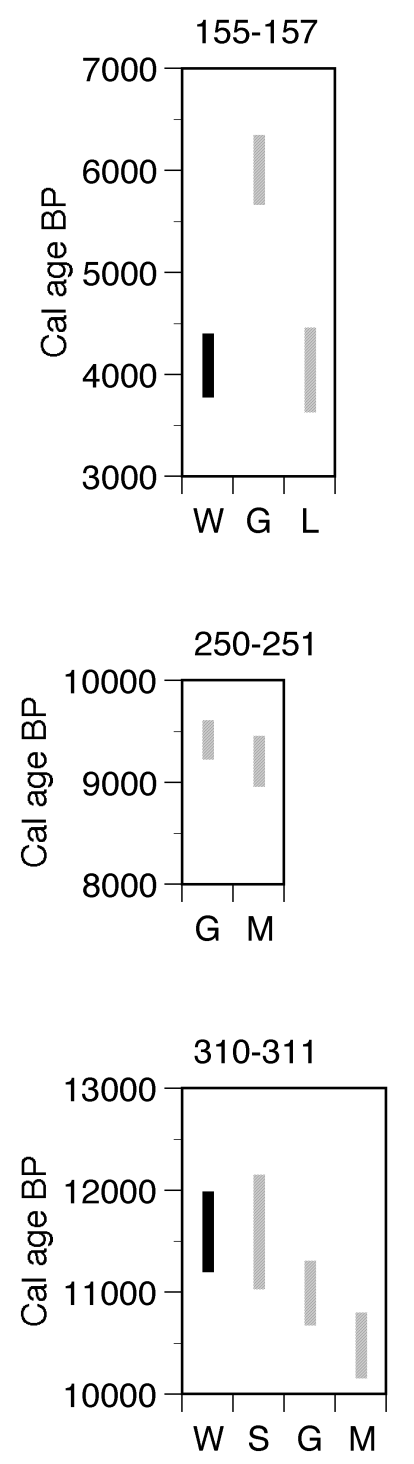

Grizzly
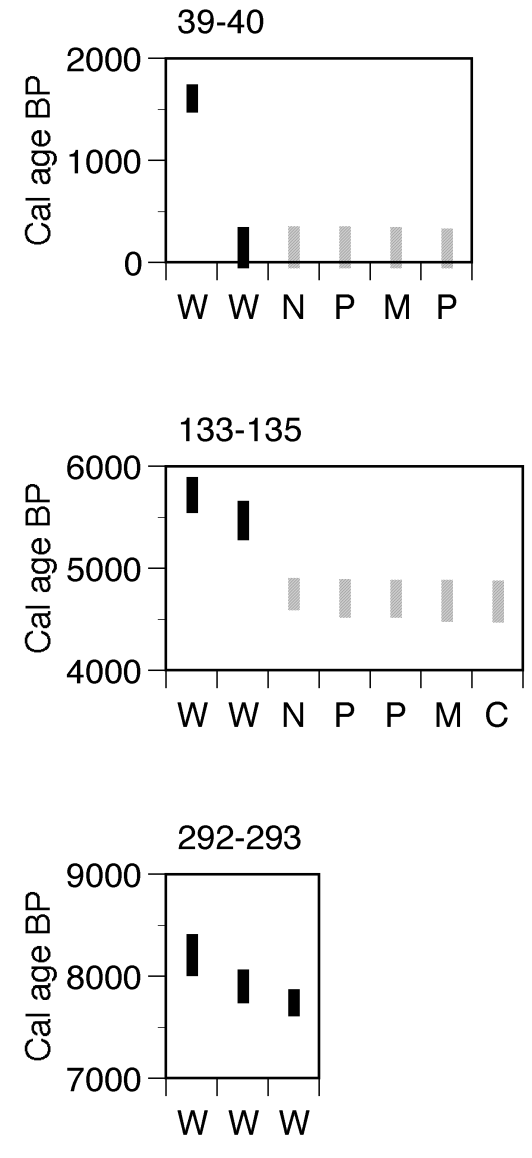

Additional
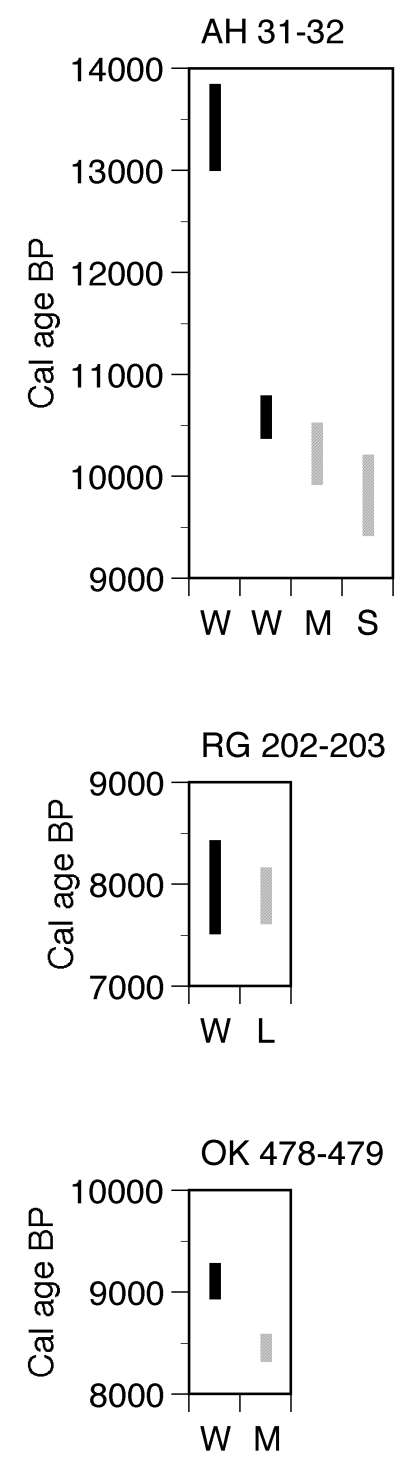

Figure 4. Oswald et al. 


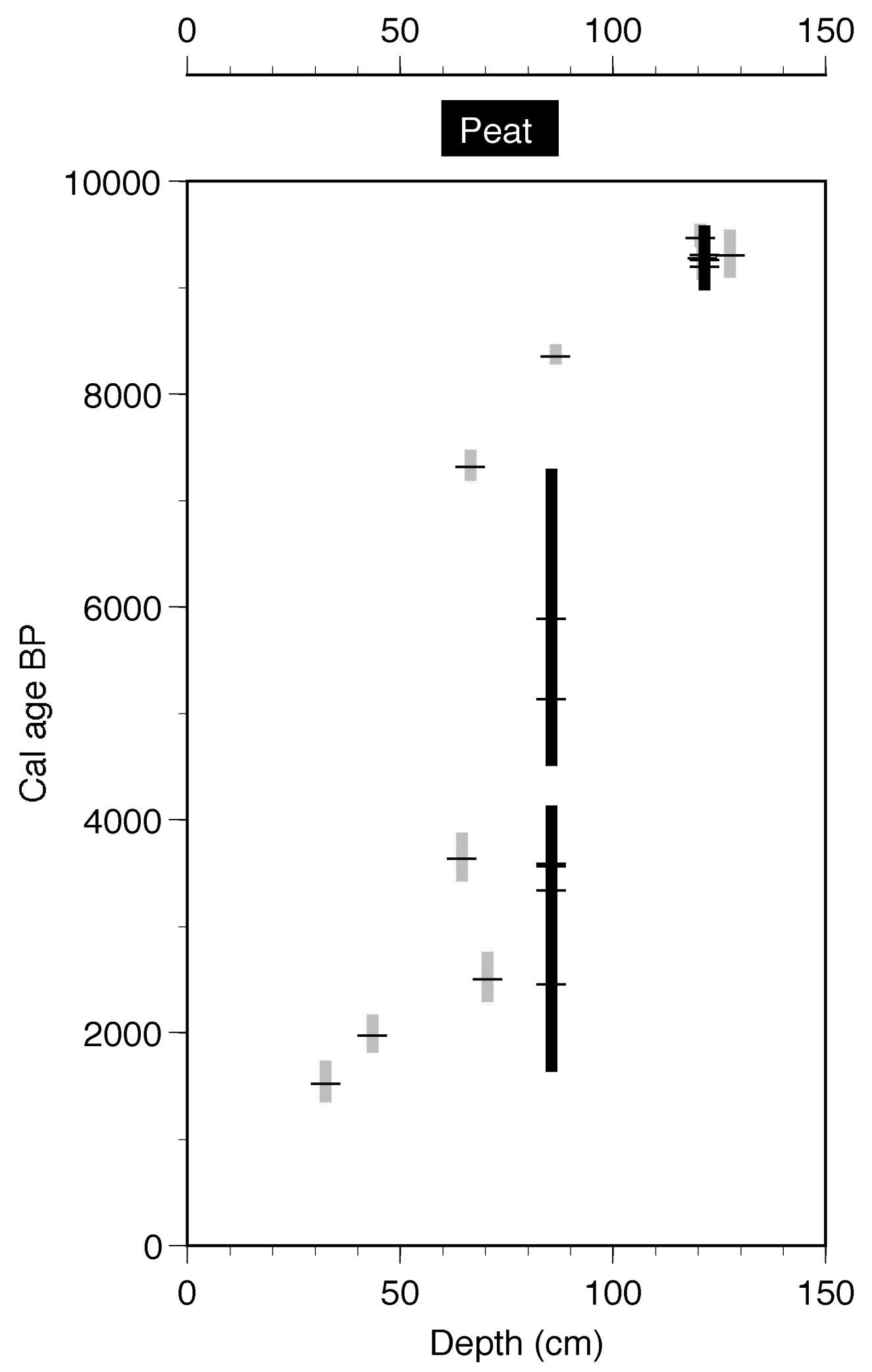

Figure 5. Oswald et al. 